\title{
Place-based education: outdoor and environmental education approaches
}

\author{
Các tiếp cận giáo dục môi trương tại thục địa \\ Short communication
}

Giap, Binh Nga*; Le, Minh Nguyet; Nguyen, Thi Hang; Duong, Thi Thuy Ha

Hanoi National University of Education, Hanoi, Vietnam

\begin{abstract}
By analyzing the relationships among place-based education, outdoor education, and environmental education, the authors developed the proposal for the practical work in place-based education and its application to guide instruction and research in Vietnam. Some examples are given as evidence.

Trên cơ sở phân tích các mối quan hệ giữa giáo dục tại thực địa, ngoài lớp học và giáo dục môi trường của những tác giả khác. Các tác giả phát triển chương trình định hướng thực hành trong giáo dục môi trường tại thực địa để ứng dụng trong giảng dạy và nghiên cứu tại Việt Nam. Các ví dụ được đề cập như là những minh chứng thực tiễn.
\end{abstract}

Keywords: community-oriented schooling, environmental education, outdoor education, place-based education

\section{Introduction}

Place-based education is a relatively new term, appearing only recently in the education literature in Vietnam. However, progressive educators have promoted the concept for a long time ago. For example, in "The School and Society" John Dewey advocated an experiential approach to student learning in the local environment: "Experience outside the school has its geographical aspect, its artistic and its literary, its scientific and its historical sides" (Dewey, 1915). Place-based education usually includes conventional outdoor education methodologies as advocated by John Dewey to help students connect with their particular corners of the world. Proponents of place-based education often envision a role for it in achieving local ecological and cultural sustainability.

Paul Theobald referred to "place-conscious" elementary and secondary classrooms in his book, "Teaching The Commons". He advocated using the immediate locale as "the lens for disciplinary engagement in all schools across the country" (Theobald, 1997). In a later article, Theobald and Curtiss (2000) described the field as "communityoriented schooling" (Theobald \& Curtiss, 2000).

Smith and Williams (1999) described this approach as "ecological education". They wrote: "The practice of ecological education requires viewing human beings as one part of the natural world and human cultures as an outgrowth of interactions between species and particular places" (Smith \& Williams, 1999). The authors outlined seven principles, two of which directly reflect outdoor education: (1) practical experiences outdoors through the application of an ethic of care, and (2) grounding learning in a sense of place through investigation of surrounding natural and human communities.

Haymes (1995) spoke directly to a "pedagogy of place" and addressed issues of race and class as they are made manifest in the construction of urban environments and in the power and politics that emerge from those constructs. His work took a cultural studies perspective and contributed a much-needed complement to more conventional outdoor curriculum and instruction (Haymes, S. N. 1995).

Thomashow (1995) wrote about the goal of achieving "ecological identity" through the examination of four basic questions: What do I know about the place where I live? Where do things come from? How do I connect to the earth? What is my purpose as a human being? He integrated these questions into activities by incorporating reflective learning in the school, home, community, and the workplace (Thomashow, M. 1995). These questions focused curriculum and instruction on understanding and appreciating students' immediate surroundings. 
So the relationships among place-based education, outdoor education, and environmental education require at least a holistic approach and then sustainability challenges need to be approached at a systemic level.

\subsection{Working definition of environmental education}

Education is a very complicated system. In order to find the optimum solution for education, careful research and decent investment are needed (Phong N.H et al, 2006.). This paper only provides models and the way to approach the problem limited to the establishment of methodology, which will be a tool to support in studying and finding solution for Vietnamese education. The model consists of 3 layers. It is constructed from the components and manysided relation (interaction) links. The kernel of the education system is a personality as a social individual with his own peculiarities of developing mind (see Figure 1).

In general, all the components, both of the same and of the different layer have impacts on each other reciprocally. This is a multi-sided relationship. However, we will study this interactive relationship with the purpose of understanding the influences on education, especially on personality as a social individual with his own peculiarities of developing mind. Different influences could be categorized into direct-indirect, main-supplementary, forward-backward.

Based on the triangle shape "developing mind", the authors developed the guidelines proposal for the practical work in environmental education (Giap, B. N. 2014).

Environmental education should be an integral part of the educational process, aimed at practical problems of an interdisciplinary character, build a sense of values, and contribute to public well-being. Its focus should reside mainly in the initiative of the learners and their involvement in action and guided by both the immediate and future subjects of concern (Stapp et all, 1998).

\subsection{Concept of environmental education}

Environmental education is a process aimed at developing a world population that is aware of and concerned about the total environment and its associated problems, and has the attitudes, motivations, knowledge, commitment and skills to work individually and collectively towards solutions of current problems and the prevention of new ones (Stapp et all, 1998).

Awareness - to help individuals and social groups acquire an awareness of and sensitivity to the total environment and its allied problems;

Knowledge - to help individuals and social groups gain a variety of experiences with the total environment and to acquire a basic understanding of the environment, its associated problems and humanity's critical responsible presence and role in it;

Attitudes - to help individuals and social groups acquire social values, strong feelings of concern for the environ- ment and the motivation for actively participating in its protection and improvement;

Skills - to help individuals and social groups acquire the skills for working toward the solution of environmental problems and to foster a dialogue between these groups;

Participation — to help individuals and social groups develop a sense of responsibility and urgency regarding environmental problems to ensure appropriate action to help solve these problems and avoid future problems.

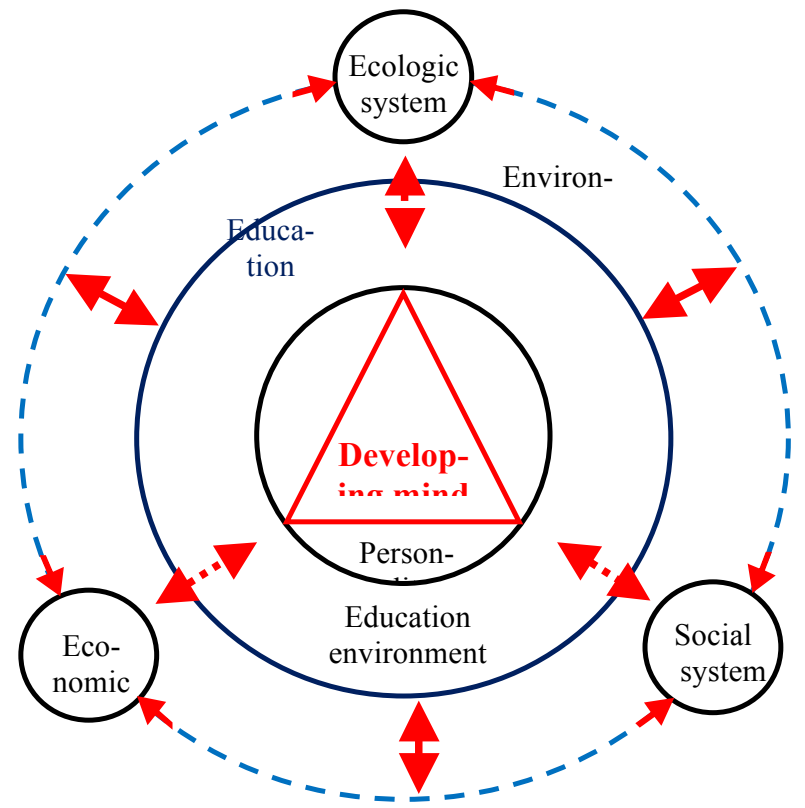

Figure 1. The model consists 3 layers: (1) External layer include ecologic, economic and social systems served as environment. (2) Education system is surrounded by educational environment. (3) Personality as a social individual with his own peculiarities of developing mind.

\section{The proposal of place-based educa- tion for the practical work}

\subsection{General objectives}

- Knowing and analysing the operation of an entity directly or indirectly related to Place-based education (Natural Parks, naturalist organisations, civic centres, educational centres, educational learning camps, municipal services, hiking clubs, human communities, etc.).

- Presenting contributions/proposals in Place-based education for the entity studied.

\subsection{Considerations}

- Work in small groups (6-8 persons).

- Each group should select the entity they wish to analyse and study.

- It is important to consider the work being carried out within the framework of the entity: its objectives, the people to whom it is directed, its operating structure, its 
financing, its educational proposals, its resources, etc.

- It is advisable, once the group is situated in the cooperating entity, to make contributions/proposals that are aimed at improving, or including, educational action in Environmental Education.

- The proposals devised should be well defined, following the guidelines proposed. The work should be original and innovative.

Being Environmental Education proposals, they should coherently and consistently integrate the conceptual, methodological and ethical components of Environmental Education (Sleurs, W., 2008).

\subsection{Practical works}

(This guideline should not be thought of as a fixed proposal, but rather as one adaptable to the necessities of each group).

PART I: Description of the entity

- Typology.

- Objectives.

- Operating structure.

- Contents/ educational proposal.

- Methodology.

- Resources.

\section{PART II: Place-based education proposal}

\section{Summary:}

- Implementation context of the proposal.

- Target public.

- Key concepts.

- Procedures to be developed.

- Attitudes and values to be encouraged.

- Expected timetable.

- Material resources and infrastructure.

\section{Development of the proposal}

- General objectives.

- Contents: conceptual, procedural, attitudinal and ethical.

- Detailed planning of the proposal: implementation process, development, etc.

- Material necessary for its implementation: guidelines, texts, images, games, work plans, sing or song, etc.

- Anticipation of new human resources, materials or infrastructure needed to carry out the proposal.

- Monitoring and evaluation of the proposal.

- Suggestions.

- Bibliography.

\section{PART III: Examples as evidence}

The authors surveyed more than 500 students from a sample of 10 secondary schools to assess levels of environmental awareness including environmental knowing, concerning and applying (Giap, B. N. 2016). The mediator relationships are found.

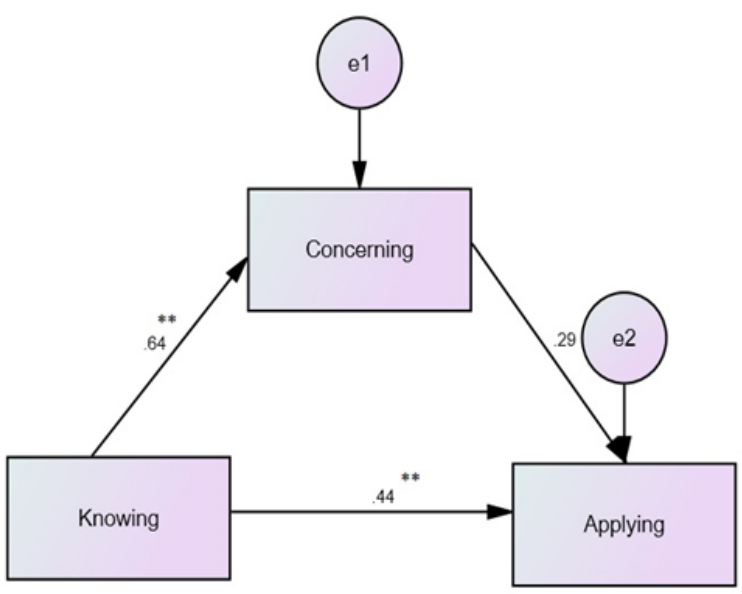

Figure 2. Mediating role of Concerning in explaining the relation between Knowing and Applying ** $p<.01$

In other researches, the authors also find some evidence that confirm mediator relationships among Awareness, Attitude and Behavior.

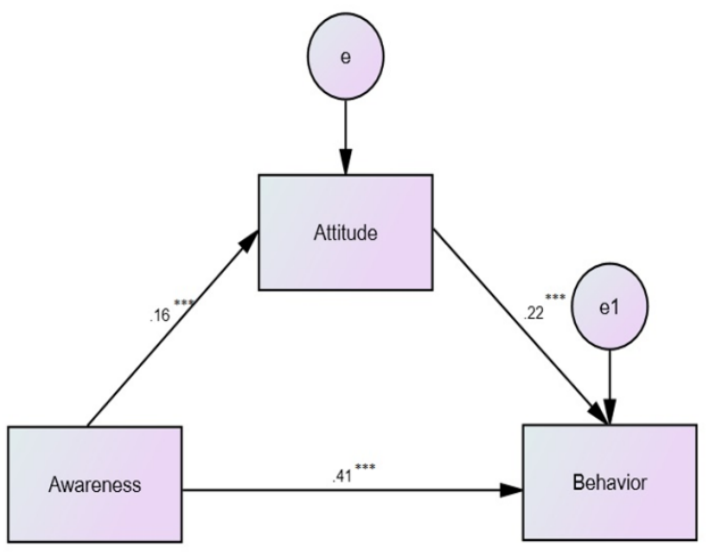

Figure 3. Mediating role of Attitude in explaining the relation between Awareness and Behavior. *** $\mathbf{p}<$ .001

\section{Conclusion}

Place-based education represents a recent trend in the field of outdoor education in Vietnam. It recaptures the ancient idea of "listening to the motherland" and living and learning in harmony with the earth and with each other. As in Vietnam society it becomes increasingly urbanized and technologized, Vietnamese educators must continue to adopt and adapt more of the goals, theory, and practice of place-based education.

\section{References}

[1] Dewey, J. (1915). The school and society (Rev. ed.). Chicago, IL: The University of Chicago Press.

[2] Giap, B. N. (2014). "Education for environment: A useful concept.". J. Viet. Env. Vol. 6, No. 3, pp. 188190.

[3] Giap, B. N. (2016). " The environmental awareness of secondary school students in Hanoi". J. Viet. Env. 
2016, Vol. 8, No. 1, pp. 62-64.

[4] Haymes, S. N. (1995). Race, culture, and the city: A pedagogy for Black urban struggle. Albany, NY: State University of New York Press.

[5] Phong, N. H., \& Hoa, N. P (2006). VIETNAMESE EDUCATION FROM THE SYSTEMATIC POINT OF VIEW.

[6] SLEURS, W. (2008). Competencies for ESD (Education for Sustainable Development) teachers. A framework to integrate ESD in the curriculum of teacher training institutes. Comenius, 2.

[7] Smith, G. A., \& Williams, D. R. (Eds.) (1999). Ecological education in action: On weaving education, culture, and the environment. Albany, NY: State
University of New York Press.

[8] Stapp, W. B., Bennett, D., Bryan Jr, W., Fulton, J., MacGregor, J., \& Nowak, P. (1998). The concept of environmental education. HUNGERFORD, Harold H.; BLUHM, William J.; VOLK, Trudi L, 33-36.

[9] Theobald, P. (1997). Teaching the commons: Place, pride, and the renewal of community. Boulder, CO: Westview Press.

[10] Theobald, P., \& Curtiss, J. (2000, Spring). Communities as curricula. Forum for Applied Research and Public Policy, 15(1), 106-111.

[11] Thomashow, M. (1995). Ecological identity: Becoming a reflective environmentalist. Cambridge, MA: The MIT Press. 